\title{
AN AMERICAN LAWYER LOOKS AT CIVIL JURY TRIAL IN SCOTLAND *
}

\author{
PaUl Hardin, III $\dagger$
}

Whatever may be the dangers of comparing supposedly analogous aspects of vastly different legal systems, every graduate of a good American law school knows the value of comparing essentially similar systems that have particular differences. That is the very stuff of legal education in this country, whose fifty states have independent but sibling legal institutions. If, however, as I suggest, apples are more profitably compared with other apples than with oranges, American lawyers might well despair of gaining immediately relevant insights about our rules of civil procedure and evidence from study abroad. Civil justice in America still revolves around the jury, while elsewhere, as we have recently been reminded, ${ }^{1}$ the jury as a means of resolving civil disputes has virtually disappeared.

Virtually, but not quite. There is at least one country-more precisely one city-outside the United States where an American jury lawyer can, once he gets used to wigs and gowns, feel completely at home. That city is Edinburgh, Scotland. Jury trials in the sheriff courts scattered throughout Scotland are infrequent, ${ }^{2}$ but each year many actions for personal injury or death are brought to Edinburgh for jury trial in the Court of Session. ${ }^{3}$ There, the Faculty of Ad-

* This Article was prepared by the author for the Comparative Study of the Administration of Justice, established under the terms of a grant from the Ford Foundation to Loyola University School of Law (Chicago), and is published here with the consent of the Study. All rights are reserved by the Study.

† Associate Professor of Law, Duke University; Visiting Associate Professor of Law, 1962-63, University of Pennsylvania. A.B. 1952, LL.B. 1954, Duke University.

The author is indebted to Mr. Ian Murray, Advocate, and Mr. William Prosser, Advocate, both of Edinburgh, Scotland, for valuable research assistance in the preparation of this Article.

1 Jolner, Civil Justice ANd the Jury 59 (1962).

2 In the 12 "busier" sheriff courts, only 61 cases were tried to juries from 1949 through 1958. Committee Appointed by the Secretary of State for Scotland, Civil Jury Trial in Scotland Report, CMD. No. 851, appendix E (1959).

3 During the period 1954-1958, the number of cases actually disposed of by jury trial in the Court of Session varied annually from 86 to 104 , and 395 jury cases awaited trial in the Court of Session at the beginning of April, 1958. Id. at 11. The Report also contains a brief summary of the history and present condition of civil jury trial in Scotland. The Committee recommended retention of jury trial in the Court of Session, but its abolition in the sheriff courts. A minority of the Committee favored doing away with the civil jury altogether. "We think it would be paradoxical if Scotland should retain an imported institution when it is in decline in England where it is indigenous." Id. at 37. 
vocates-probably numbering fewer than 100 advocates in active practice-constitute perhaps as busy a body of jury lawyers as may be found anywhere outside our own country. ${ }^{4}$

I spent last summer observing jury trials in Scotland, talking with lawyers and judges there, and reading what I could find on their rules of procedure and evidence. I discovered some intriguing differences between Scottish and American practice, rendered all the more pungent by the startling similarity in the respective basic institutions of civil justice. The purpose of this Article is to outline briefly and informally a few of the areas in which Scottish practice diverges from our own, and in which American lawyers might find interesting and helpful comparisons. For the sake of convenience and general interest, the comparisons will be made chiefly in terms of personal injury cases.

\section{Pleading and Other Pretrial Procedures}

Although I shall be dealing for the most part with the trial stage of litigation, I first want to touch lightly on some pretrial problems.

Judged by American standards of reformed procedure, pleading and other pretrial mechanisms in Scotland are old fashioned. Discovery techniques are not streamlined, pretrial hearings as we know them are not utilized, and the pleadings carry most of the burden of framing the issues and giving notice of facts to be proved at trial. ${ }^{5}$

The pursuer's (plaintiff's) initial pleading is called the summons. It contains, in addition to certain formal parts, the "conclusions" (prayer for relief), the "condescendences" (allegations of facts giving rise to the suit, set forth in numbered paragraphs), and the "pleas in law" (legal propositions relied upon in support of the conclusions). Thus, the pursuer has to state his claim in considerable factual and legal detail. As one would suspect, this means that a considerable amount of court time is consumed by the Scottish equivalent of our de-

\footnotetext{
4 The Scottish bar is divided; only adrocates are permitted to appear in the Court of Session.

$5 \mathrm{We}$ are fortunate in having available in this country a thorough exposition of Scottish pleadings. Millar, Civil Pleading in Scotland (pts. 1-2), 30 MrcH. L. REv. 545,709 (1932). This article was prepared with the assistance of the then Lord President of the Court of Session, and was hailed in Scotland as perhaps being a fuller study than anything which had been published in Scotland up to that time. Note, An American Lawyer's Impression of Scottish Pleading, 1933 Scots L.T. 137. The following articles and note may help to convey the Scots' own impressions of Scottish pleading. Blades, The Art of Pleading (pts. 1-2), 64 Scor. L. REv. 25, 53 (1948); Walker, Pleadings in Negligence, 72 Scor. I. REv. 241 (1956); Note, The Right to Amend, 67 Scor. L. Rev. 212 (1951).

6 See Cleary, The Uses of Pleading, $40 \mathrm{Ky}$. L.J. 46, 54 (1951); Millar, supro note 5 , at 740 .
} 
murrer practice, ${ }^{7}$ and that too much trial time is spent in quibbling over whether or not the pursuer's averments give proper notice of lines of evidence and legal theories sought to be developed at trial. If this seems archaic when compared with practice under the Federal Rules of Civil Procedure, it is little different from and no worse than pleading practice in many of our states.

But all of this is by way of leading up to something that is unique. The defender's (defendant's) pleading must deal with each allegation of fact in the summons in a manner quite similar to special denial practice under the Federal Rules. That is, the defender, in a separate numbered answer for each of the pursuer's numbered condescendences, answers every material allegation as either "admitted," "denied," or "not known and not admitted." These correspondingly numbered answers may also contain new matter, averred by way of explaining or avoiding the pursuer's allegations. After the defenses are served, the pursuer prepares what is known as "the open record" (pronounced re-cord'). This is best described as an integrated reproduction of the summons and defenses, including conclusions, pleas in law, and the like, but also containing the condescendences of the pursuer and the answers of the defender set out in parallel-condescendence (1) followed by answer (1), condescendence (2) followed by answer (2), and so on.

Now the fun begins. Even before he serves a copy of the open record on the defender, the pursuer's counsel, in the light of the defender's answers and, possibly, of further investigation of the case, makes certain "adjustments" in his condescendences. He does this by interlining a word, phrase, or sentence here and there, using perhaps blue ink. The defender's counsel, who has seen the pursuer's adjustments and has also had a chance to look into the case a bit further, then makes adjustments in his answers, being careful to use, say, red ink. This process goes merrily on, back and forth, usually for four weeks, unless counsel sooner exhaust either their ingenuity or their vari-colored inks. After this period of informal and completely unsupervised amendment of the pleadings, the court "closes the record." 8 The pursuer then has the onus of preparing a document known as the "closed record." This is simply a clean reproduction of the by

7 The Scottish "plea to the relevancy" of the pursuer's summons is not an exact equivalent of the demurrer, as it is pleaded along with, rather than in advance of, the factual defenses. Millar, stpra note 5, at 568, 742 .

8 The case is actually called at the end of two weeks, but one continuance is allowed as a matter of course. The period of adjustment may be continued after the second fortnight, but only on cause shown. In practice, the adjustment period is almost always four weeks. See CT. of SEsS. R. 115, 116; Note, Adjustment of Record, 1932 Scors L.T. 73. 
now colorfully marked-up open record; it embodies the pleadings in final form, save the possibility of amendment by opening up the closed record-an expensive process which is much less flexible than "adjustment." 8

Do any useful insights for the American lawyer lurk in this unique procedure? Happily, most of our cases nowadays encounter little delay or difficulty at the pleading stage, but instead are at issue in a matter of weeks. ${ }^{10}$ This is in part the result of reforms in the formal rules of pleading; but, particularly in metropolitan litigation centers, pleading shortcuts and efficiencies seem also to have developed spontaneously, without sweeping revision of rules and statutes. To adopt matter-of-course revision of the pleadings in the Scottish fashion would be to take a giant step backward. ${ }^{11}$ On the other hand, not all American cases are yet free from pleading troubles. Even in metropolitan areas, some cases bog down in a morass of pleading complications; ${ }^{12}$ and this is presumably the fate of a greater percentage of cases in rural counties of states which have not adopted liberal pleading rules. The Scottish experience with record adjustment at least demonstrates that most preliminary skirmishes at the pleading stage can be handled by the lawyers, more or less informally, without costly court supervision, and also without proliferation of documents in the file. Paradoxically, even as we have de-emphasized pleadings, we have saddled our judges with potentially troublesome supervisory duties related to the pleadings. ${ }^{13}$ On the other hand, the Scots, who still attach great importance to pleading, seem to get along nicely without court supervision until matters have been pretty thoroughly aired.

I have already indicated that discovery procedures in Scotland are not as well developed as in the United States. Depositions and interrogatories, which are routinely used here, are available in Scottish practice only to preserve the testimony of a prospective witness who is aged or dying, or who is outside of or about to leave the juris-

9 Professor Sunderland has dẻscribed the hearing at which the Court of Session closes the record as an early instance of pretrial hearings. Sunderland, The Theory and Practice of Pre-Trial Procedure, 36 Mrce. L. REv. 215, 220 (1937). By like token, the closed record can be analogized in a limited way to our pretrial order, as it governs the subsequent conduct of the case. It must be recognized, however, that this is a rudimentary pretrial hearing only, at which little more is done than to settle pleadings.

Amendment after the record is closed is dealt with in CT. of SESS. R. 117.

10 See, e.g., Levin \& Woolley, Dispatch and Delay: A Fiferd Study of Judicial AdMinistration in PenNSYLVANIA 256-57, 296 (1961).

11 Pleading reform had so far progressed in this country that Professor Millar was able to make this point a full generation ago. Millar, supra note 5, at 738-39.

12 See, e.g., Levin \& Woolley, op. cit. supra note 10, at 258-62.

13 See Fed. R. Civ. P. 7 (a); Chadbourn \& Levin, Cases on Civil Procedure 351 (1961). 
diction. ${ }^{14}$ There is a device in Scotland for the discovery of documents, whether in the hands of parties or non-parties, ${ }^{15}$ but its scope is strictly limited by the averments in the record. One case which I observed illustrates this point. Rather close to trial, the defender was informed that the pursuer had, at a prior time in life, sustained injuries that were very similar to those which he now claimed were recently caused by the defender's misconduct. Before the defender could discover the hospital records relating to the earlier injuries, he had to move the court to open the closed record so that he could insert in his answers "on belief" a specific averment of facts to support his request for production of the documents. This procedure, of course, is awkward and time consuming. Furthermore, there is always the danger that the court will not permit a party to amend the record, on the ground that he is merely attempting to insert random averments so as to have "a fishing search." 16

Nonetheless, the Scots have certain pretrial practices with respect to documentary and real evidence that tend to minimize surprise at the trial and to streamline the ultimate handling of "productions" in court. The first of these is the requirement that any party who intends to introduce documents, plans, maps, models, and other productions must "lodge them in process" at least one week before trial, or later by leave of court. ${ }^{17}$ This means that these items must be filed in court and thus made available for inspection by the opposing party. Furthermore, items which are so lodged acquire identifying numbers, making it quite easy for lawyers and court officials to keep track of things and call them to the attention of witnesses. Incidentally, documents which lawyers plan to use solely for impeachment of witnesses need not be lodged in advance of trial; ${ }^{18}$ so a possibility of surprise is preserved in an area in which it may be thought to be legitimate.

A second pretrial device that serves to streamline the introduction of documentary evidence is called a "minute of admissions." 19 The

14 The Evidence (Scotland) Act, 1866, 29 \& 30 Vict. c. 112; Lewis, MaNUaL of THE LAW of Evidence IN ScotLand 181, 184 (1925). See also Millar, supra note 5 , at 745 .

15 By written specification of the documents desired, a party craves the court to grant "commission and diligence" for their recovery. CT. OF SESS. R. 120-123. Rule 125 provides that a party can demand that his opponent admit the date, signature, transmission, receipt of any relevant document, or the verbal accuracy of any copy under penalty of having to pay the expense of proof rendered necessary by refusal to admit.

18 Pattinson v. Robertson, [1843-44] Sess. Cas. 944, 951 (Scot. 2d Div. 1844). It was interesting to learn that the Scots also apply the fishing metaphor when they do not approve of discovery.

17 CT. of Sess. R. 129.

18 Paterson \& Sons v. Kit Coffee Co., 16 Scots L.T.R. 180 (1908) ; Lewis, op. cit. supra note 14 , at 189-90.

19 CT. of SEsS. R. 142. 
major contribution of this paper, prepared by counsel just before trial, is to eliminate or diminish tiresome authentication at trial of writings, photographs, and the like. Naturally, there are occasional fights over the authenticity of documents, but no more than seem to occur in American jurisdictions utilizing pretrial hearings. Thus, for example, when it becomes desirable to refer to the hospital records in a personal injury case, counsel will simply ask whatever witness he has on the stand to "refer to number 11 of process, if you please." A court official will then hand the hospital file to the witness, and counsel can directly begin his substantive questioning. He does not have to put a custodian witness on the stand to establish that these are indeed the hospital records pertaining to the treatment of the pursuer.

One other Scottish pretrial procedure will no doubt provoke mixed reactions in the United States. If, as trial approaches, the defender feels that he may go down to defeat, he may lodge a "tender" - a written offer to the pursuer to pay a certain sum in settlement of the claim. If the pursuer rejects the tender and ultimately recovers a verdict in a sum no greater than the amount of the tender, he will be charged with all expenses of the litigation after the date of tender. ${ }^{20}$ This Scottish rule is similar to statutory provisions in some of our states. ${ }^{21}$ It is more potent, however, in that expenses in all Scottish civil cases include lawyers' fees. The rule of tender may appear at first blush to favor defenders because it obviously places great pressure on pursuers to accept these formal settlement offers. However, pursuers need feel no pressure to accept unreasonable offers, and there seems to be agreement that the device encourages defenders to make fair proposals. ${ }^{22}$ Both the taxation of reasonable attorneys' fees as part of court costs and the adoption of a tender rule are worthy of serious consideration in the United States. ${ }^{23}$

20 Maclaren, Expenses in the Supreme Court and the Sheriff Courts of Scotrand 81 (1912). See also Ramsay v. Souter, [1863-64] Sess. Cas. 891, 892 (Scot. 2d Div. 1864).

21 See Note, 53 Colung. L. Rev. 78, 86 (1953).

22 Note, Scottish Practice as to Tenders in Libel Actions, 1933 Scors L.T. 49.

23 Professor McCormick has argued ably in support of taxing attorneys' fees as part of court costs:

Upon balancing the opposing considerations, it seems probable that the English practice, which allows reimbursement with fair completeness of counsel fees and actual expenses in favor of the successful party, is more just and equitable than the American rule limiting recovery to the inadequate arbitrary statutory scale of costs, and has a greater tendency to lessen the flow of litigation.

McCormxck, Damages 255 (1935) ; see Note, Use of Taxable Costs to Regulate the Conduct of Litigants, 53 CoLum. L. REv. 78, 94 n.126 (1953). 


\section{The TRIAL \\ A. Selecting the Jury}

Scottish counsel have very little to do with the selection of jurors. The court clerk ballots the jurors by drawing slips from a box and asking the persons whose names and numbers are drawn to take their places in the jury box. Each side does have four peremptory challenges, ${ }^{24}$ but they are exercised most unobtrusively, if at all. If an advocate wishes to challenge a juror, he simply will nod to the clerk when he hears the name of that juror called. The clerk will then say to the juror, "You needn't come," and draw another name. This goes on until twelve jurors have been successfully ballotted from the panel of 36 . Theoretically, there can be challenges for cause, ${ }^{25}$ but they practically never occur. Indeed, it is hard to see how it could be otherwise, for counsel do not have the privilege of questioning the panel or even of asking the court to question them. ${ }^{26}$ Apparently, all that the advocates have to go on is a list of the 36 prospective jurors, indicating the occupations of those who are employed. Since the peremptory challenges are frequently exercised on the basis of the professions or occupations of the jurors, more men than women are challenged. The result is that women outnumber men on many juries even though the ballot box originally contains the names of 18 men and 18 women. ${ }^{27}$

I doubt that the Scots lose much in foregoing the ancient and honorable rite of examining the jury panel. Certainly there is a consistent gain offsetting any occasional disadvantage; the jury is ready to take its oath and hear the case two to five minutes after the ballotting begins.

\section{B. The Rules of Evidence}

After the jury has been sworn and has heard a brief opening statement by the pursuer's counsel, the time comes for the "leading" of evidence. ${ }^{28}$ The rules governing the introduction of evidence in Scotland and America present some interesting comparisons.

24 Jury Trials (Scotland) Act, 1815,55 Geo. 3 , c. $42, \S 21$.

25 Ibid.

26 I have found no direct authority holding that counsel may not examine jurors. Scottish lawyers agree, however, that it is not done, and suggest as indirect authority that the statutes that authorize and refer to challenge make no reference to examination. E.g., Jury Trials (Scotland) Act, 1815, 55 Geo. 3, c. 42, $\$ 21$; Court of Session Act, 1868, 31 \& 32 Vict. c. 100, $\$ 44$ (Scot.).

27 CT. OF SESS. R. $138(\mathrm{c})$.

28 The defender's opening statement is postponed until after the pursuer has led his evidence, in contrast to the practice in some American states. 


\section{The Oath}

Oral testimony of sworn witnesses presented during examination and cross-examination in open court is the accepted method of proof in Scotland, as in the United States. ${ }^{29}$ Perhaps I should, therefore, at least touch upon the oath, for there is reason to believe that if the witness' oath ever achieves the desired effect, it does so in the Court of Session. In the first place, the oath has an optional clause, much used in Edinburgh, that portends doom for the false swearer. ${ }^{30}$ (The unbeliever and the witness whose beliefs forbid oathtaking may, of course, affirm.) ${ }^{31}$ In the second place, the oath is administered, not by the clerk in a singsong voice, but by His Lordship, who stands and stretches his own right hand high in company with the witness as he solemnly intones. Perjury doubtless occurs in Scotland, but it must be attended by considerable uneasiness when the oath has been administered as I heard it done, for example, by Lord Milligan of the Court of Session.

Able-bodied witnesses stand throughout the giving of their testimony in Scotland. This also contributes to an atmosphere that seems rather more solemn than the atmosphere surrounding American jury trials.

\section{Out-of-Court Statements of the Dead and Insane}

Perhaps my most exciting discovery in Scotland was the fact that the Scots readily admit, as an exception to the rule against hearsay, the out-of-court statements of persons who are dead at the time of trial. $^{32}$ The only requisites to admission are, first, that the declarant would be a competent witness and his statement admissible if he were present to testify, and, second, that the statement be nonlitigious-that is, not made expressly for use in litigation. ${ }^{33}$ There is authority that supports the admission, under the same enlightened rule, of statements

29 Mackay, Evidence and Procedure in Scotland: A Comparison With England, 14 MODERN L. REv. 162, 170 (1951).

30 The optional clause is printed here in brackets: "I swear by Almighty God [and as I shall answer to God at the great day of judgment] that I will tell the truth, the whole truth, and nothing but the truth." LEwIs, op. cit. supra note 14, at 116. In Edinburgh, of course, "truth" sounds more like "trrruth," which makes it all the more impressive to the tourist, though probably not to the Scotsman in the witness box.

31 The Oaths Act, 1888, 51 \& 52 Vict. c. 46 . See generally Note, Upon Your Oath, 77 Scor. L. REv. 101 (1961).

32 Lewis, op. cit. supra note 14, at 133 ; BeLL, PRINCIPLes of THE LAW of Scotland $\$ 2259$ (1899); Dickson, A Treatise on the Law of Evidence in Scothand $\S 266(1887)$.

33 LEwIs, op. cit. supra note 14, at 133, 136. 
of persons who are hopelessly insane at the time of trial. ${ }^{34}$ What can one say at this point but "Bravo!"

\section{3. "De Recenti" Statements}

Another rule involving hearsay implications-and a rule of some practical importance in Scottish personal injury cases-concerns "de recenti" statements. When a party to a civil case, or a prosecuting witness in a criminal case, has been injured, evidence that immediately or very shortly after his injury he reported or complained of it is admissible if the party or prosecuting witness has first taken the stand himself and given testimony concerning the occurrence. ${ }^{35}$ The doctrine was very early extended to admit evidence of de recenti statements of a child witness who testifies concerning crimes or other occurrences, even though the child may not have been injured in any way. ${ }^{36}$ "In order that the de recenti statement may become admissible, substantive evidence of the transaction or offense to which the statement is referable must to some extent first be led." ${ }^{37}$ I was told by Scottish advocates that the statements are admitted only to bolster the credibility of the party, prosecuting witness, or child. The authorities, however, do not clearly state this limitation and in some passages even seem to belie it. ${ }^{38}$

If the rule operates to admit de recenti statements as substantive evidence, I feel it has much to commend it. Such fresh statements of an interested party or witness are more likely to be true than their testimony at trial. But I would approve of the rule even if it has only the limited purpose of bolstering the credibility of witnesses. It would be a useful antidote to whatever tendencies jurors might have to discredit the testimony of complainants in injury cases and of child witnesses in general. Incidentally, no Scottish lawyer with whom I spoke was in the least disturbed by what would undoubtedly cause dismay in some courts in this country, the fact that the rule permits the introduction of de recenti statements supporting the credibility of a witness before his credibility has been attacked. The de recenti rule may remind American lawyers of our narrower rule relating to

34 Id. at 134.

35 Id. at 326; Dickson, op. cit. supra note 32, § 258.

36 H.M.A. v. Stewart, 2 Irvine 166, 179 (Scot. High Ct. 1855).

37 Lewis, op. cit. supra note 14 , at 326 .

38 Dickson, op. cit. supra note $32, \$ 258$ states that de recenti statements can constitute corroboration under the rule discussed infra in the text. This clearly implies substantive use. Furthermore, the text writers all seem to treat the doctrine as involving an exception to the hearsay rule, which is at least a debatable point if it is not being used to prove the truth of the matters asserted. 
"outcry" in rape cases, about which there is even similar confusion as to whether or not the statements come in as substantive evidence. ${ }^{39}$

\section{Corroboration}

Potentially the most important difference between the rules of evidence in Scotland and the United States is that in the former country the uncorroborated testimony of one witness is not sufficient to make out a civil or criminal case. ${ }^{40}$ In other words, the essential elements of a case must be proved by evidence from more than one source, or, applying the rule to personal injury cases, the pursuer must produce either an eyewitness or some circumstantial evidence to support his own testimony on every essential fact. ${ }^{41}$ I speak of this difference as potentially important because I do not know how strictly the rule is applied. However, I doubt that the corroboration requirement would or should be looked upon with favor in the United States. If corroboration is easily "found," as it seemed to be in the civil cases which I observed, it would only be a nuisance. On the other hand, if the rule has real force in practice, it must make some meritorious personal injury and death claims virtually impossible to establish. ${ }^{42}$

\section{The Scope of Cross-Examination}

American courts disagree on whether the cross-examination of a witness should be limited in scope to matters raised on direct examination or whether it may properly extend to all matters relevant to the controversy. How strange to a Scotsman the restrictive or federal rule

39 Professor McCormick reports that courts frequently say that the victim's complaint made soon after an alleged rape comes in solely to support credibility, but expresses his own view that this rationale "is a modern sophistication designed to reconcile the admission of this ancient evidence of 'hue and cry' with the modern ban upon hearsay. To say that prompt complaint does not substantively strengthen the state's case runs counter to common sense." MCCORMICK, EvidenCE § 49, at 109-10 n.27 (1954).

40 Stewart v. City of Glasgow, [1958] Sess. Cas. 28 (Scot. 1st Div. 1957); LEwIS, op. cit. supra note 14 , at 246 ; BELL, op. cit. supra note 32 , $\$ 2257$.

41 The second source need not be direct evidence of a second witness; it may be circumstantial. "In this matter the substance rather than the form should be regarded, and wherever the evidence truly depends on the observation, memory, or truthfulness of one person alone, it is to be regarded as the testimony of a single witness." LEWIS, op. cit. supra note 14, at 246.

42 An Englishman, commenting on corroboration in Scotland, took a less jaundiced view. "In any event, the corroboration rule, although at times decried and at times leading to mere mechanical repetition, has still got its uses if applied with discretion." Mackay, Evidence and Procedure in Scotland: A Comparison With England, 14 Modern L. Rev. 162, 171 (1951).

In criminal cases, the corroboration rule may have both importance and merit in the prosecution of serious offenses. See Wilson, The Logic of Corroboration, 76 Scot. L. REv. 101 (1960). However, it seems unnecessarily inefficient for lesser crimes. An almost ludicrous illustration of this is the fact that traffic wardens in Edinburgh work in pairs in order to get convictions for overtime parking. 
must seem. Not only may a party to a Scottish case cross-examine opposing witnesses on matters not explored on examination-in-chief, but he must do so as to essential elements of his own case about which the witnesses would be expected to know, or risk being barred from proving those facts by his own witnesses. ${ }^{43}$ In a case arising out of an automobile accident, for example, if the defender expects to show that a third automobile was present and contributed in some way to the accident, he must ask the pursuer and his witnesses about the presence and role of the third car. If he omits this line of inquiry, the court will not permit him to question his own witnesses about it when he later presents his case.

This cross-examination rule, to the extent that it eliminates the need for rebuttal testimony, promotes trial efficiency. On the other hand, it clearly undercuts whatever tactical advantage defenders could otherwise enjoy by presenting their own theories initially through friendly witnesses. I view the open American rule, applied with discretion, as a desirable middle point between the Scottish rule and the restrictive American rule.

\section{Post-Accident Safety Measures}

One further difference between Scottish and American rules of evidence lies in the area of post-accident safety measures. American courts have almost universally excluded proof of repairs to defendants' machinery or premises following an accident when the evidence is offered to show negligence generally. ${ }^{44}$ Such proof is thought to have little or no logical tendency to show that the particular defendant was unreasonable in failing to discover and guard against the danger before the accident. ${ }^{45}$ Courts and commentators who have difficulty with this relevancy argument still accept the exclusionary rule on the ground that to admit such evidence might discourage the taking of steps to remove a danger. ${ }^{46}$ Administering the rule, however, involves some difficulty, because the evidence is unquestionably admissible for limited purposes, such as to show ownership or control of the premises or to show the feasibility of taking safety precautions. ${ }^{47}$ If, therefore, we

43 Whenever it is intended to lead evidence to contradict what a witness has stated in his examination-in-chief, or to explain facts known to him though not so spoken by him, care must be taken to cross-examine the witness upon the facts as they are subsequently proved. Failure to do so may disentitle the party to lead evidence of the facts he wishes to prove.

Lewrs, op. cit. supra note 14, at 226. (Emphasis added.) See also Stewart v. City of Glasgow, [1958] Sess. Cas. 28, 38 (Scot. 1st Div. 1957).

442 Wigmore, Evidence $\$ 283$ (3d ed. 1940).

45 Morris, Torts 51 (1952).

46 MCCORMTCK, Evidence $\$ 77$, at 159 (1954).

47 Ibid.; MORRIs, ToRTs $52-54$ (1952). 
could determine that the rule of exclusion is practically impotent or unnecessary in the matter of encouraging repairs, and if we had some assurance that juries could be trusted not to give evidence of repairs more weight than it logically merits, we might give serious thought to reform. At this point, Scottish law and practice seem to offer rather important insights.

In Scotland, where the majority of jury cases involve claims by employees against employers for injuries sustained at work, ${ }^{48}$ it is customary for the parties to inquire of witnesses what was done following the accident with respect to the allegedly offending machinery, platform, or what have you. This evidence is freely admitted, without limiting instructions. ${ }^{49}$ Scottish lawyers were surprised when $I$ told them that we exclude this kind of evidence for fear that juries might misuse it and for fear that its admission would discourage defendants from taking valuable post-accident safety precautions. The consensus among the Scots was that jurors do not pay much attention to this sort of evidence and that the practice of admitting it does not inhibit repairs.

This comparison suggests that our rule may be based upon an ill-founded fear of prejudice and that it may even be working in "reverse." Scottish lawyers insist that they do not caution their clients to postpone repairs, even though evidence of them will be admitted. On the other hand, it is well known that American lawyers sometimes advise clients to put off certain improvements until after trial, just to be extra safe, lest the remedial measures should somehow come to the attention of the jury and be given undue weight. How strange it would be to discover that excluding evidence of post-accident repairs so as not to discourage them actually does tend to discourage them by building up in the minds of defendants' lawyers an exaggerated fear of jury prejudice. In other words, perhaps we have so feared prejudice and so mistrusted the rule with its various exceptions that we have in a measure defeated the very laudable policy which the rule theoretically serves.

\section{Tradition of Restraint in Objecting}

A striking difference is observable between Scotland and the United States in the admission and exclusion of evidence that has

48 Of the 395 jury cases awaiting trial in the Court of Session in April, 1958, 280 were master and servant cases, while 86 were road traffic cases. Civil Jury Trial in Scotland Report, op. cit. supra note 2 , at 11.

${ }_{49} \mathrm{My}$ only direct authority for this statement is my own observation, supported by discussion with advocates. I can cite as implied authority the absence of any treatment of this subject in the texts which I read. Apparently, admissibility of post-accident repairs is not questioned in Scotland today. 
nothing to do with the "rules" governing admissibility. Scottish lawyers are far more restrained in objecting to offers of evidence by their opponents than are their American counterparts. I am bound to say that Scottish lawyers themselves insist that the practice varies from advocate to advocate, and we all know that the propensities of American lawyers in this regard range from extreme laissez faire to picayunish carping. Furthermore, my observations in Edinburgh lasted only a few weeks. On the other hand, the paucity of objections attracted my attention in the first case that I observed, and I paid closer attention to this feature of the trials than perhaps to any other. I therefore have some confidence in the soundness of my generalization and am sure that the unusual tolerance of Scottish advocates in this respect has important practical consequences.

Before attempting to illustrate my point, I should note one exception to it, which was obliquely referred to in the discussion of pleadings. Quibbling at trial is frequent on the one question of whether or not the closed record gives fair notice of the facts sought to be proved by particular testimony or by a certain document. I heard, on the average, five or six such objections in each civil jury trial that I observed. This was, however, the only ground on which any evidence was objected to in several trials; I sat occasionally for three or four consecutive days without hearing, for example, a single hearsay objection, despite constant violation.

The theory concerning leading questions is the same in Scotland as in America. On direct examination, leading questions generally may not be asked except as a time-saving device in bringing out preliminary or uncontested matters. ${ }^{50}$ In practice, however, there are far more leading questions asked and far fewer objections interposed in Scotland than in this country, even when counsel are asking about matters that are hotly debated and crucial to the case. When opposing counsel's patience is finally exhausted, instead of objecting and seeking to have the question disallowed, he is apt simply to rise and say resignedly, "Question and answer." When I observed that the judges never made any ruling at this point, I was told that no ruling is expected. The "question and answer" formula has been carried over from non-jury cases; apparently, its main purpose is to cause the shorthand reporter to record the particular question and answer verbatim, rather than to lump them into the commonly used paraphrased narrative form. This enables the appellate court to see the manner in which the testimony was elicited and, hopefully, to weigh

50 LEwIs, op. cit. supra note 14 , at 217 ; DICKson, op. cit. supra note 32 , $\$ 1771-73$; Bishop v. Bryce, [1910] Sess. Cas. 426, 431 (Scot. 1st Div.). 
it accordingly. But even this mild sort of protest is infrequently made, and orthodox objections to leading questions are rarer still.

Notwithstanding my distaste for repeated objections to the form of questions, I have reason to believe that in this particular area of leading questions, Scottish leniency has led to sloppy practice. Certainly there was little effort on the part of many advocates whom I observed to avoid leading. Testimony on the most crucial matters seemed antiseptic and not very persuasive, even when witnesses were obviously articulate and could have made a fine impression under proper interrogation. ${ }^{51} \mathrm{I}$ am inclined to believe that the failure to appreciate the tactical advantages of non-leading interrogation is related in some way to this tradition of withholding objections to leading questions.

In theory, the opinion rule also operates in Scotland just as in the United States. Lay witnesses should testify to facts, not opinions. ${ }^{62}$ Opinion testimony is especially proscribed on matters near the heart of the controversy-questions of ultimate fact or mixed law and fact. It seems to be settled, for example, that "a witness may not be asked whether a certain person acted with propriety." 53 The Scottish tradition of restraint in objecting, however, effectively liberalizes the opinion rule, just as it does the leading question rule. For example, I saw two cases tried on successive days in which the pursuers were workers claiming to have been injured at their jobs as a result of breaches of duty by their employers. In both cases, substantially the following testimony was elicited without objection.

Counsel: Do you consider that the place where you were working was a safe place to work?

Pursuer: No.

Counsel: Would it have been practicable for your employer to take measures to make the place safe?

Pursuer: Yes.

51 The best example is taken from a criminal trial which I observed. The crown called to the stand a poised and bright looking young police constable, who with his fellow officers had allegedly been assaulted by the prisoners in the dock. The procurator-fiscal was not content with leading his witness through introductory matter. When he reached the really exciting details of the fight, he was still looking down at his notes of earlier interviews with the witness and carrying on in a rather bored manner: "I believe, Constable Riekes, that it was at this time that a tall youth in a dark suit jumped on you from behind and wrestled you to the ground." And so it went, the prosecutor "testifying" and the witness being ail but wasted except for looking neat in his uniform and occasionally nodding or murmuring acquiescence to the unfolding story. This probably saves time, but the jury does not get a spontaneous and graphic description of the events.

52 LewIS, op. cit. supra note 14, at 45; Dickson, op. cit. supra note $32, \S 391$.

63 Ibid. LEwIs, op. cit. supra note 14 , at 215 , gives these further examples of improper questions: "Did the defender negligently run down the pursuer?"; "Did the accused murder the deceased?" 


\section{Counsel: What measures?}

Pursuer: A guard rail could have been erected around the staging.

The first two questions would almost certainly have been objected to by American lawyers and quite likely excluded by most of our courts; they were framed literally in the terms of the statute which created the duties allegedly breached by the defenders. ${ }^{54}$ It would be difficult to find better examples of opinion testimony on the ultimate issues for the jury. Here, however, unlike the area of leading questions, the Scots' liberality seemed to produce no unfavorable results. ${ }^{55}$

On the whole, the advocates' policy of interposing few objections appeals to me. It achieves an effective and salutary liberalization of the evidence rules at the trial level. However, restraint in raising objections is a good substitute for genuine reform of the rules of evidence only when counsel do not abruptly step out of character, and only when the trial judge captures the spirit of tolerance. I think that I should share with the reader the rather amazing case which provided me with that insight.

It was a personal injury case, the first one that I observed which involved the use of hospital records. I soon realized that both parties were making perfectly free use of the pursuer's hospital records with never an objection being interposed. First one witness and then another would read, at the request of counsel for both parties, miscellaneous excerpts from the records, including several items that would not be admissible in this country under all of the hearsay exceptions combined. I was soon convinced that by some marvelous statute or decision, all entries in hospital records were admissible in Scotland to prove the truth of the matter asserted therein. The case lasted just

54 "There shall, so far as is reasonably practicable, be provided and maintained safe means of access to every place at which any person has at any time to work, and every such place shall, so far as is reasonably practicable, be made and kept safe for any person working there." Factories Act, 1961, 9 \& 10 Eliz. 2, c. 34, §29(1). (Emphasis added.)

$55 \mathrm{My}$ notes on the first case that I observed in Edinburgh contain another example of practical liberality in the opinion rule area. The case involved an automobile accident. One of the witnesses was asked: "If the man had not run forward, could the driver of the car have avoided him?" There was no objection, and the answer was "Yes, definitely." Of course questions of that type are sometimes approved here, but they have been so often disapproved that Dean Wigmore once characterized an Alabama case taking the liberal view as "indeed a Daniel come to judgment, in comparison with other rulings . . ." 7 WIGroRe, Evidence \& 1976, at $123 \mathrm{n} .1$ (3d ed. 1940).

The same case provided two other interesting items of testimony involving the problem of a witness' opportunity to form a sound opinion. First, a police constable, without objection, was permitted to express his opinion, based upon the odor of an auto driver's breath, that the driver had had "several pints." Later in the trial, another witness, with similarly acute senses, was permitted to give his opinion of the speed of an auto which he had not seen in motion, but whose tires (tyres in Scotland) he had heard screeching on the roadway. 
under two days, and I suspect that half of the total bulk of the hospital records of the pursuer had been read to the jury by the time the defender rested his case. Both counsel made their closing arguments, and since $I$ had by then gotten over my initial shock that hospital records were so freely bandied about, I neither noted at the time nor now remember how much reliance the advocates placed upon the hospital records in their summaries. I am certain that both counsel referred to the records to some extent. Just before the court was to give instructions, the pursuer's counsel, to my utter amazement, moved the court to instruct the jury to disregard every reference that had been made to the pursuer's hospital records, except items that were either admitted by the pursuer to be true, or testified to by the persons who actually made the entries in question. My amazement turned to despair when the judge excused the jury and asked for argument, and then to something approaching grief when he granted the motion. The judge granted that motion even though it was first made after final arguments, even though the pursuer's counsel himself had elicited matters that did not meet his own now-expressed requirements for admissibility, and even though he had failed to interpose a single objection to the defender's use of the hospital records during the presentation of evidence.

During the argument on the pursuer's motion, the judge expressed his frustration at this experience which apparently had occurred in his court at least once before. ${ }^{56} \mathrm{He}$ asked counsel how, in future cases, they might avoid the situation of having all parties make free use of hospital records and then having one party ask the judge at the eleventh hour to take the inadmissible matters from the jury. The defender's counsel deferentially suggested that some earlier objection might well have been taken by his opponent, but the argument seemed to be lost on everyone in the courtroom except me. Of course, the outcome of the case was not affected, because the judge gave the requested instruction without emphasis and because the jury could not

56 I have since learned that another Court of Session judge had made a formal statement about this careless use of hospital records in a 1961 case.

The practice has grown up of recent years of parties admitting hospital records. This practice is often for the convenience of the Court and avoids the necessity of calling medical witnesses at personal inconvenience to identify such records. To that extent the practice has much to commend it. If, however, all that parties have agreed is that the records are records appertaining to the pursuer, such an agreement does not cover the facts contained in the records and certainly does not cover expressions of medical opinion therein. If, therefore, either party wishes to found on the facts contained in the records, arrangements should be made with the other side to have the facts admitted, and if such an arrangement cannot be made, someone from the hospital staff with personal knowledge of the case should be adduced to speak to the facts.

McHugh v. Leslie, 1961 Scots L.T. (Notes) 65 (Outer House). 
have followed it in any event. But the entire episode was incredible to an American onlooker.

\section{Jury Argument}

In Scotland, the pursuer's counsel makes the first argument to the jury, but does not present a rebuttal argument. This struck me as being a significant difference between Scottish and American practice, since most trial lawyers attach some importance to having the last word.

Two things about the manner in which advocates argue to the juries caught my attention. First, the arguments of pursuers' advocates seemed moderate and restrained to one who is accustomed to American personal injury trials. This is partly attributable to the Scottish rules about arguing damages which are far more restrictive than the rules in many of our states; ${ }^{57}$ but again tradition probably plays a larger role. ${ }^{58}$ The concept of the "adequate award" 58 obviously has not come to Edinburgh, and even an ex-defendants' lawyer is tempted to say that counsel for pursuers undertry their cases. I might add that the size of verdicts lends some support to this assertion. ${ }^{60}$

The second thing that I noticed about the manner of arguing applies to defenders as well as pursuers. This is entirely a subjective reaction that should not be unduly emphasized, but it seemed to me that there is a greater gulf between advocate and juror in Scotland than between lawyer and juror in America. The ingredients of this phenomenon, if it does exist outside of my own imagination, are the wigs and gowns, the highly cultivated accent and tone of Edinburgh advocates, and the natural tendency of most Scottish people to treat each other with something less than the hale-fellow-well-met manner of many Americans. Somehow I cannot imagine a Scottish advocate

57 Scottish advocates may not suggest to the jury formulae for computing amounts or even total sums as awards for pain and suffering. In practice, they explain to the jury that the total amount claimed in the pursuer's pleading was a purely artificial maximum limit and that the jury should ignore that figure and return a moderate and reasonable sum for pursuer's pain and suffering. For a good general discussion of damages in personal injury cases, see WALrer, The LAW of DaMAges IN ScotLAND 578-81 (1955).

58 This same tradition of moderation and restraint is a noticeable feature of the prosecutors' jury arguments in Scottish criminal cases. Allowing again for individual differences among American prosecutors and among Scots, the manner of Scottish prosecutors seems on the whole much less partisan than that of prosecutors in the United States.

59 See Belli, The Adequate Award, 39 Calif. L. Rev. 1 (1951). See generally Belit, Modern Darrages (1959).

60 WALKER, op. cit. supra note 57, at 796, sets out, in an appendix, brief descriptions of some 150 or so personal injury claims of the late $1940^{\circ} \mathrm{s}$ and early $1950^{\circ} \mathrm{s}$, and states the amount awarded in each case. The sums are quite modest by our standards, even after allowance is made for national differences in the cost of living. 
getting "folksy" with a jury, perhaps permitting his speech to lapse into the vernacular. This should not, however, be understood as a criticism of the Scots, nor as a suggestion that jury argument is less effective in Scotland than in this country. In fact, I was most favorably impressed by the brevity and relevancy of the advocates' summations. Probably the dignity of wig, gown, cultivated speech, and that certain aloofness is at least the equal of the rapport or identification of the American trial lawyer with his jurors.

\section{E. Instructions and Verdict}

In his instruction to the jury, the Scottish judge is permitted to comment on the evidence. In practice, this is handled with appropriate moderation, but without squeamishness. A recent American study of comment seems to show that it "make[s] the jury neither more nor less like the judge." o1 If this is so, arguably we should omit judicial comment in all cases, in the interest of saving time. On the other hand, if comment has no prejudicial effect, it seems needless, and costly from the standpoint of appeals, to require trial judges to avoid it circumspectly in those cases in which some sort of summary or review of the evidence is needed or perhaps even requested by the jury.

In certain areas of jury instruction, the Scots have achieved a clarity that has eluded us in this country. When instructing on the burden of proof in civil cases, for example, Scottish courts properly focus the jurors' attention on their own state of mind rather than on a mechanical weighing of evidence in search of a preponderance. "The pursuer has the burden to satisfy you by the balance of probabilities . . . "The "satisfy you" clause reminds me of the Alabama formula-reasonably satisfy-to which I became accustomed in practice and which has Professor McCormick's approval. ${ }^{62}$ The "probabilities" aspect of the Scottish instruction fits in reasonably well, though not perfectly, with the recommendations of one of our most thoughtful commentators. ${ }^{63}$ Certainly from the standpoint of common sense, satisfaction on probabilities is more descriptive of what we are after than proof by the "greater weight" of evidence or any other such formula.

Another instance of simple clarity in Scottish jury instructions occurs in the "Issue for the Pursuer," submitted to the jury in every

61 JoINer, CIVIL JUSTICE AND THE JURY 214 (1962), quoting Kalven, Report on the Jury Project, in Confrerence on Ams and MeThods OF LEgal Researcr (Conard ed. 1955).

62 MCCORMICK, EVIDENCE § 319, at 678 (1954). (1944).

e3 McBaine, Burden of Proof: Degrees of Belief, 32 CALIF. L. REv. 242, 246-50 
negligence case, and the "Counter-Issue for the Defender," submitted when the defender alleges contributory negligence. By the former, the jury is asked whether the pursuer's injuries were caused to any extent by the "fault of the defender"; by the latter, whether to any extent by the "fault of the pursuer." How refreshing it was to hear juries questioned in terms simply of "fault," which every juror understands, rather than burdened with such mishmash as "failure to exercise the care of a reasonably prudent man." In sum, I found that instructions to the jury in the Scottish cases that I observed were briefer, more pungent, and more helpful to the jury than instructions usually given in this country.

Now that we have the Scottish civil case in the hands of the jury, there is but one further contrast to describe. In both civil and criminal cases in Scotland, a verdict may be found by a simple majority of the jury. ${ }^{64}$ Probably the ideal lies somewhere between the Scottish simple majority and the American unanimous verdict, ${ }^{65}$ but I should be sorely tempted to settle for the simple majority in civil cases. In Edinburgh, when the jury go out at noon, one can wait for the verdict and not miss lunch!

64 Administration of Justice (Scotland) Act, 1933, $23 \& 24$ Geo. 5, c. 41, $\$ 11$.

65 "Deliberation so essential to good decision-making and fact-finding does not require unanimity. However, it does require more than a majority verdict, for the give-and-take of discussion is essential." JoINER, op. cit. supra note 61, at 82 . See also id. at 201-02, quoting Kalven, supra note 61 . 